\title{
Independent bilateral primary bronchial carcinomas
}

\author{
M. RAY CHA UDHUR I
}

Department of Anatomic Pathology, Medical Faculty of Rotterdam, The Netherlands

\begin{abstract}
Independent bilateral primary bronchial carcinomas are not common. Since Beyreuther's description in 1924, 16 well-documented cases of independent primary bronchial carcinomas of different histology have been described. From 1965 to 1970, eight cases were seen at the London Chest Hospital. In order to make the diagnosis of a second primary bronchial carcinoma, each tumour should be malignant and neither should be a metastasis from the other. To meet this last criterion, the histopathological features of the two tumours must be different. Many cases have been described in the literature as double primary bronchial carcinomas where the second primary had the same histological features as the first.
\end{abstract}

A patient with one primary cancer is more likely to develop another than would be expected from chance alone. Multiple carcinomas of paired organs, such as the breasts and ovaries, are not infrequent, and may be synchronous or nonsynchronous (Moertel, 1964 ; Mersheimer, Ringel, and Eisenberg, 1964 ; Fauvet, Chavy, and Piet, 1964). Since Billroth's initial report in 1914 multiple primary visceral carcinomas have been of perennial interest to pathologists. At present their general incidence ranges from 1 to $4 \%$ of all cancer patients (Carvalho and Ferraro, 1966). In contrast, the development of two primary carcinomas in the lungs is an unusual phenomenon. In most published series of bronchial carcinomas, no mention at all is made of double primaries. Beyreuther (1924) was the first to describe such a case-a well-differentiated keratinizing squamouscell carcinoma in the right lung and an adenocarcinoma in the left. Since then 16 well- documented cases of double primary bronchialü carcinomas with different histological structureshave been described (Table I). In making the diagnosis of two separate bronchial carcinomas, certain accepted criteria must be fulfilled. Warren and Gates (1932), Cahan, Butler, Watson, and Pool@ (1950), LeGal and Bauer (1961), Leafstedt, Sweet- $\frac{\circ}{\Phi}$ man, Chester, and Thorpe (1968), and Mobley and Martinez (1968) assert that, in order to make the $\stackrel{\circ}{3}$ diagnosis of a second primary bronchial carcinoma, each tumour should be separate from the other, each should be malignant, and neither should be a metastasis from the other. In order to meet this last criterion, the histopathological features of the two tumours must be entirely: different. Many cases, including the case of 3 . Mobley and Martinez, have been described as examples of double primary bronchial carcinomas, $\frac{\circ}{3}$ although the second primary had a histological structure similar to the first. In these circumstances,

TABLE I

REPORTED CASES OF WELL-DOCUMENTED INDEPENDENT BILATERAL PRIMARY BRONCHIAL CARCINOMAS

\begin{tabular}{|c|c|c|c|}
\hline No. of Cases & Year Reported & Author & Histopathology \\
\hline $\begin{array}{l}1 \\
1 \\
1 \\
1 \\
1 \\
1 \\
2 \\
1 \\
1 \\
1 \\
1 \\
1 \\
1 \\
1 \\
1 \\
1 \\
1\end{array}$ & $\begin{array}{l}1924 \\
1932 \\
1954 \\
1955 \\
1957 \\
1958 \\
1958 \\
1959 \\
1959 \\
1962 \\
1964 \\
1964 \\
1964 \\
1967 \\
1968\end{array}$ & $\begin{array}{l}\text { Beyreuther } \\
\text { Pirchan and Sikl } \\
\text { Chauvet and Feuardent } \\
\text { Kainberger } \\
\text { Fuchs } \\
\text { Robinson and Jackson } \\
\text { Newman and Adkins } \\
\text { Azzopardi } \\
\text { Mandel and Thomas } \\
\text { Onuigbo } \\
\text { Watson et al. } \\
\text { Shields et al. } \\
\text { Clifton et al. } \\
\text { Castleman } \\
\text { Leafstedt et al. }\end{array}$ & $\begin{array}{l}\text { Squamous +adenocarcinoma } \\
\text { Squamous +oat-cell ca. } \\
\text { Squamous + oat-cell ca. } \\
\text { Squamous +oat-cell ca. } \\
\text { Squamous +adenocarcinoma } \\
\text { Squamous + adenocarcinoma } \\
\text { Squamous +adeno+oat-cell + alveolar-cell ca. } \\
\text { Squamous +oat-cell ca. } \\
\text { Squamous +adenocarcinoma } \\
\text { Squamous + adenocarcinoma } \\
\text { Squamous +oat-cell ca. } \\
\text { Squamous +alveolar-cell ca. } \\
\text { Squamous +adenocarcinoma } \\
\text { Squamous +oat-cell +alveolar-cell ca. } \\
\text { Squamous + adenocarcinoma }\end{array}$ \\
\hline
\end{tabular}


the possibility of a metastasis rather than a second primary is very strong and can never be ruled out (Struve-Christensen, 1966).

The purpose of this paper is to tabulate those cases of independent bilateral primary bronchial carcinomas in which the histology of the two tumours was completely different and to present a further eight cases seen at the London Chest Hospital between 1965 and 1970 (Table II). These eight cases were seen out of a total of 632 cases of bronchial carcinoma, of which 413 were surgical specimens and 219 were taken at necropsy.

T A B L E I I

PRESENT CASES OF INDEPENDENT BILATERAL PRIMARY BRONCHIAL CARCINOMAS

\begin{tabular}{|c|c|c|c|c|c|c|}
\hline \multirow{2}{*}{ Case } & \multicolumn{3}{|c|}{ First Primary } & \multicolumn{3}{|r|}{ Second Primary } \\
\hline & Year & Site & Histology & Year & Site & Histology \\
\hline J.L. & 1967 & R.U.L. & Squamous-cell ca. & 1969 & L.H. and & Oat-cell ca. \\
\hline $\begin{array}{l}\text { J.E.W. } \\
\text { H.A. } \\
\text { J.G. } \\
\text { J.C. }\end{array}$ & $\begin{array}{l}1967 \\
1962 \\
1967 \\
1965\end{array}$ & $\begin{array}{l}\text { L.U.L. } \\
\text { L.H. } \\
\text { R.L.L. } \\
\text { L.H. }\end{array}$ & $\begin{array}{l}\text { Squamous-cell ca. } \\
\text { Squamous-cell ca. } \\
\text { Squamous-cell ca. } \\
\text { Adenocarcinoma-well- } \\
\text { differentiated, mucus-secreting }\end{array}$ & $\begin{array}{l}1970 \\
1970 \\
1969 \\
1970\end{array}$ & $\begin{array}{l}\text { R.H.L.L } \\
\text { R.L.L. } \\
\text { L.L.L. } \\
\text { R.L.L. }\end{array}$ & $\begin{array}{l}\text { Oat-cell ca. } \\
\text { Poorly-differentiated adenocarcinoma } \\
\text { Oat-cell ca. } \\
\text { Undifferentiated carcinoma of large polygonal } \\
\text { cell type }\end{array}$ \\
\hline $\begin{array}{l}\text { J.M. } \\
\text { W.M. } \\
\text { R.C. }\end{array}$ & $\begin{array}{l}1954 \\
1958 \\
1957\end{array}$ & $\begin{array}{l}\text { L.H. } \\
\text { R.M.L. } \\
\text { L.L.L. }\end{array}$ & $\begin{array}{l}\text { Squamous-cell ca. } \\
\text { Squamous-cell ca. } \\
\text { Squamous-cell ca. }\end{array}$ & $\begin{array}{l}1967 \\
1969 \\
1967\end{array}$ & $\begin{array}{l}\text { R.U.L. } \\
\text { L.U.L. } \\
\text { R.U.L. }\end{array}$ & $\begin{array}{l}\text { Poorly-differentiated adenocarcinoma } \\
\text { Oat-cell ca. } \\
\text { Oat-cell ca. }\end{array}$ \\
\hline
\end{tabular}

R.U.L. =right upper lobe; L.U.L. = left upper lobe; R.M.L. = right middle lobe; R.H. = right hilum; L.H. =left hilum; R.L.L.=right lower lobe; L.L.L. $=$ left lower lobe

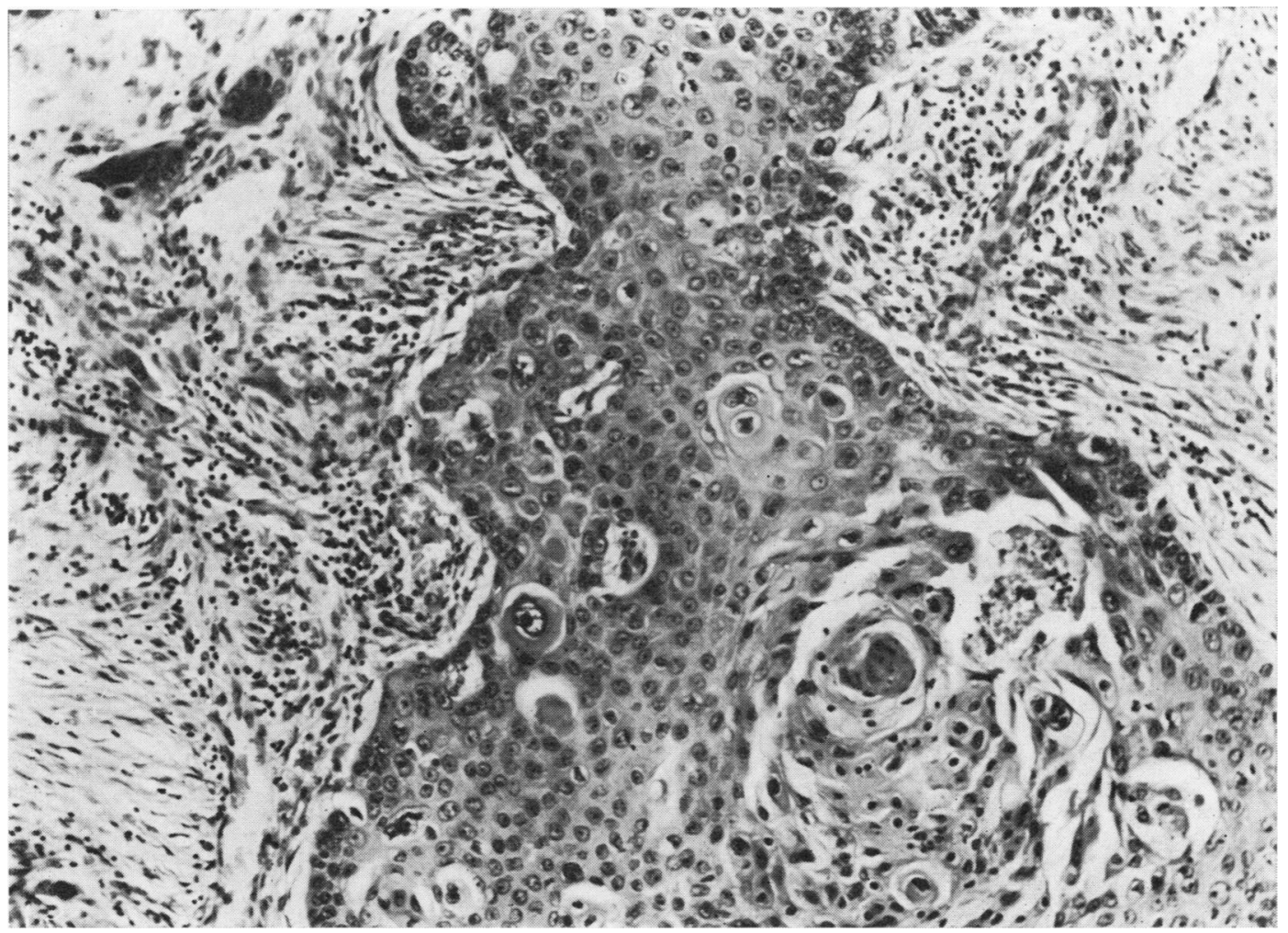

FIG. 1. Growth in the right upper lobe. Histologically it is a well-differentiated keratinizing squamous-cell carcinoma. Haematoxylin and eosin $\times 235$. (see text). 


\section{ILLUSTRATIVE CASE}

J.L., a 60-year-old goods checker, who had smoked 40 cigarettes a day for over $\mathbf{4 0}$ years, was admitted in May 1967 for investigation and treatment of a right upper lobe shadow. He had a long history of chronic bronchitis, cough productive of yellow sputum, and haemoptysis once in the last eight years. Clinically no abnormality was detected. Bronchoscopy was normal and neoplastic cells were not found in the sputum. In view of his poor respiratory function, surgical intervention was not indicated and the patient was kept under constant supervision. He was finally admitted in September 1969 with severe dyspnoea and diminished movement and dullness over the whole right upper lobe and the left upper lobe anteriorly. His condition deteriorated so quickly that a repeat bronchoscopy was not possible.

At necropsy, a large fungating tumour, $6 \times 5 \times 3 \mathrm{~cm}$, was found at the apex of the right upper lobe. The tumour extended laterally into the chest wall, which was densely infiltrated. The left lung contained a large hilar growth, $5 \times 4 \times 4 \mathrm{~cm}$, with an extension, $3 \times 2 \times 2 \mathrm{~cm}$, in the anterior basal segment of the lower lobe. The left cerebral and cerebellar cortices, the liver, and the suprarenals as well as the hilar and mediastinal lymph nodes were infiltrated.

Histologically, the right upper lobe growth was $a \frac{\bar{C}}{0}$ well-differentiated keratinizing squamous-cell car- $\overline{\bar{c}}$ cinoma with metastases in both the cerebral and cere- $\frac{\vec{D}}{\Phi}$ bellar cortices (Fig. 1). The hilar and peripheralo growths of the left lung, and the metastases in the lymph nodes and both suprarenals, showed oat-cellcarcinoma with typical pseudorosette pattern (Fig. 2) Both types of growth were present side by side in $\vec{\omega}$ the liver (Fig. 3).

\section{DISCUSSION}

When a patient has two histologically distinct primary bronchial carcinomas, one on each side, के to prove that each is separate and independent is often difficult. It is known that any bronchialcarcinoma may present widely different histologi- $\frac{\complement}{=}$ cal features in different areas (Kreyberg, 1962 Willis, 1967 ; Ashley and Davis, 1967). In a necropsy study of 255 patients who died of primary bronchial carcinoma, Auerbach, Stout,

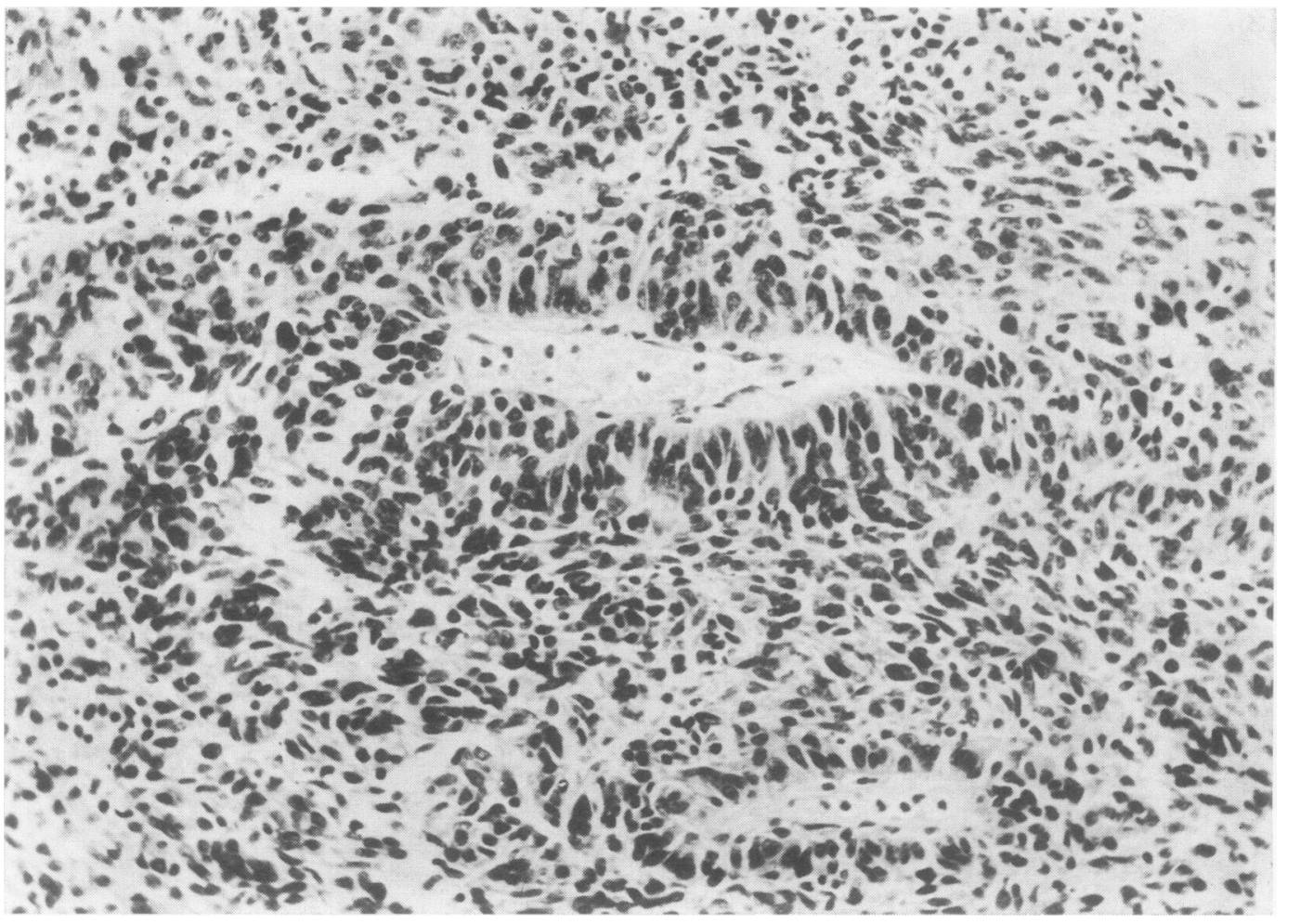

FIG. 2. Growth in the left hilum. Histologically it has the features of an oat-cell carcinoma. H. and E. $\times 145 .($ see text). 


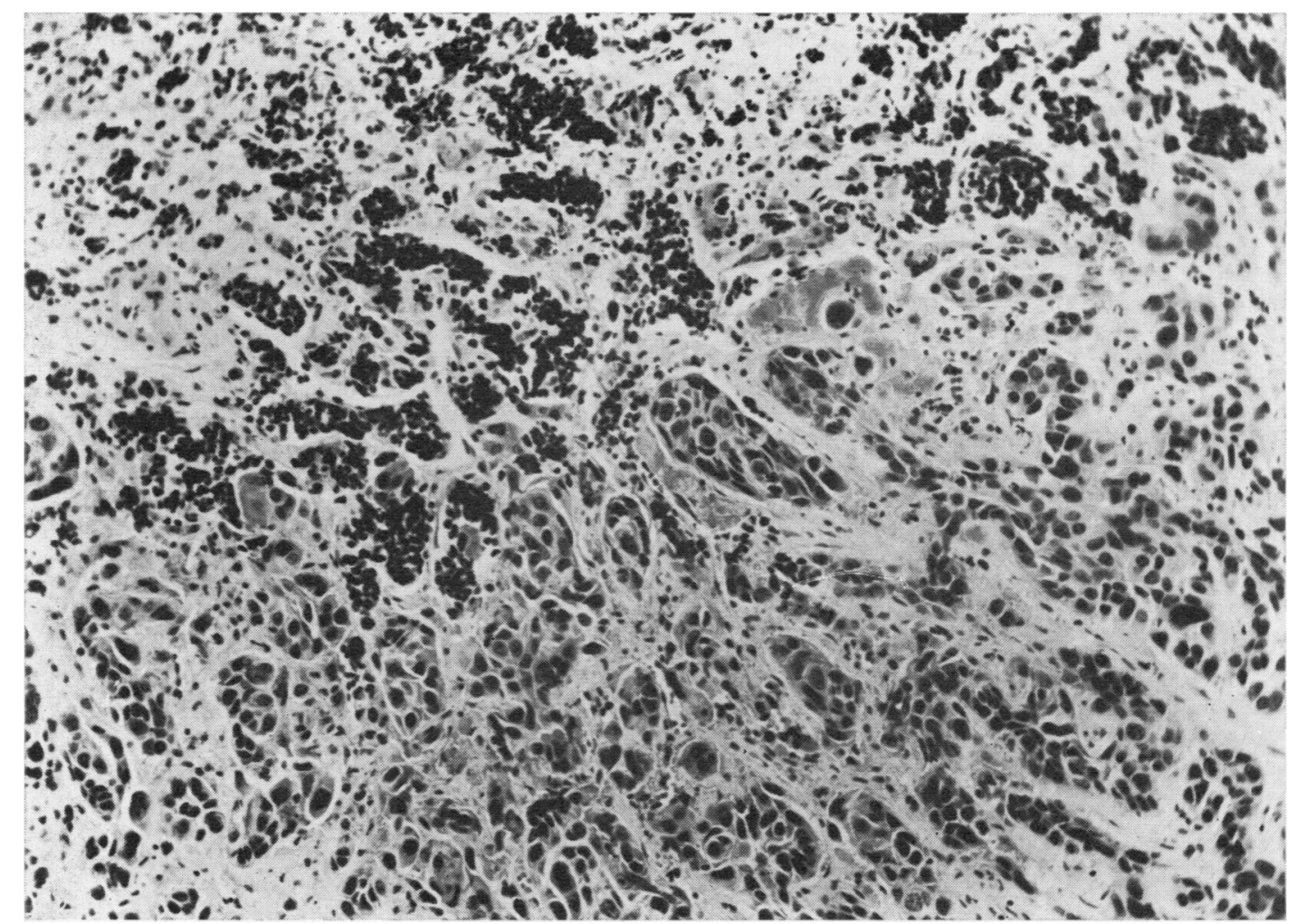

FIG. 3. Metastases in the liver, showing characteristic squamous-cell and oat-cell carcinoma side by side. H. and E. $\times 240$. (see text).

Hammond, and Garfinkel (1967) found nine cases of multiple invasive growths of different histological patterns, an incidence of $3.5 \%$. In the present series, this amounts to only $1.2 \%$.

Leafstedt et al. (1968) argued that the respiratory epithelium tends to become metaplastic because it is in a dynamic state of constant renewal and is exposed to numerous irritants. Carcinogenesis is not an isolated biological accident, but probably the result of continued exposure to cigarette smoking, atmospheric pollution, and other irritants, which finally initiates irreversible malignant changes in the epithelium. It is hardly surprising that the process may continue in the same or opposite lung or in the residual bronchi left after resection of a bronchial carcinoma.

An interesting feature of these independent bilateral primary bronchial carcinomas is that most of them were squamous in character in the first primary and incidentally became either poorly differentiated adenocarcinoma or oat-cell carcinoma or undifferentiated carcinoma of large polygonal cell type. In the present series, five out of these eight cases showed oat-cell pattern in the second primary: of the remaining three, two were poorly differentiated adenocarcinomas and the other was an undifferentiated carcinoma of large polygonal cell type. The case illustrated confirms the histological differentiation by showing separate types of growth side by side in the metastases, particularly in the liver. In no other examples cited previously has this unique character of independent bilateral primary bronchial carcinomas been depicted. The most plausible explanation is the divergent differentiation of the original multipotent cancer cell, which can express itself in metastases in different organs.

I am indebted to Dr. K. F. W. Hinson, Director of Pathology, Brompton Hospital, and Mr. J. R. Belcher, Consultant Surgeon, the London Chest Hospital, for their advice and criticism. I thank the physicians and surgeons of the London Chest Hospital for allowing me to report their patients; Mr. K. G. Moreman, Chester Beatty Institute, for the photographs; and 
Mr. V. Jones, the London Chest Hospital, for technical help.

\section{REFERENCES}

Ashley, D. J. B., and Davies, H. D. (1967). Mixed glandular and squamous-cell carcinoma of the bronchus. Thorax, 22, 431 .

Auerbach, O., Stout, A. P., Hammond, E. C., and Garfinkel, L. (1967). Multiple primary bronchial carcinoma. Cancer (Philad.), 20, 699.

Azzopardi, J. G. (1959). Oat-cell carcinoma of the bronchus. J. Path. Bact., 78, 513.

Beyreuther, H. (1924). Multiplicität von Carcinomen bei einem Fall von sog. "Schneeberger" Lungenkrebs mit Tuberkulose. Virchows Arch. path. Anat., 250, 230 (1924).

Billroth, T. (1914). Die allgemeine chirurgische Pathologie und Therapie in 51 Vorlesungen, p. 908. Reimer, Berlin.

Boucot, K. R., Weiss, W., and Cooper, D. A. (1965). Second pulmonary neoplasms among long-term survivors of lung cancer. Amer. Rev. resp. Dis., 92, 767.

Cahan, W. G., Butler, F. S., Watson, W. L., and Pool, J. L. (1950). Multiple cancers: primary in the lung and other sites. J. thorac. cardiovasc. Surg., 20, 335.

Carvalho, A. G., and Ferraro, D. T. (1966). Multiple cancers. J. Kans. med. Soc., 67, 494.

Castleman, B. (1967). Weekly clinicopathological exercises. New Engl. J. Med., 277, 147.

Chauvet, M., and Feuardent, R. (1954). Cancer bronchique bilateral. J. franc. Méd. Chir. thor., 8, 377.

Cliffton, E. E., Das Gupta, T., and Pool, J. L. (1964). Bilateral pulmonary resection for primary or metastatic lung cancer. Cancer (Philad.), 17, 86.

Fauvet, J., Chavy, A., and Piet, R. (1964). Les cancers primitifs multiples. Rev. Prat. (Paris), 14, 2149.

Fuchs, U. (1957). Zur Frage der Lungen-Doppelcarcinome. Langenbecks Arch. klin. Chir., 285, 29.

Kainberger, F. (1955). Über einen Fall von doppeltem primärem Bronchus-Karzinom. Klin. Med., 10, 354.

Kreyberg, L. (1962). Histological lung cancer types. A morphological and biological correlation. Acta path. microbiol. scand., suppl. 157.

Leafstedt, S. W., Sweetman, W. R., Chester, C. L., and Thorpe, J. D. (1968). Multiple primary neoplasms of the lung. J. thorac. cardiovasc. Surg., 55, 626.
Le Gal, Y., and Bauer, W. C. (1961). Second primary bronchogenic carcinoma-a complication of successfu lung cancer surgery. $J$. thorac. cardiovasc. Surg., 41, 1140

Mandel, W., and Thomas, J. H. (1959). Simultaneous? occurrence of squamous and adenocarcinoma of th lung. Calif. Med., 91, 358.

Mersheimer, W. L., Ringel, A., and Eisenberg, H. (1964) Some characteristics of multiple primary cancers. Ann N.Y. Acad. Sci., 114, 896.

Mobley, D. F., and Martinez, A. J. (1968). Two histologicall $\overrightarrow{\mathrm{y}}$ different primary carcinomas of the lung. A review of the literature and presentation of a case. Cancer (Philad.).
22, 287 .

Moertel, C. G. (1964). Incidence and significance of multipl primary malignant neoplasms. Ann. N.Y. Acad. Sci, $114,886$.

Newman, W., and Adkins, P. C. (1958). Three primary carcinomas of the lung arising in a left lower lobe wit? metastasis of two of the tumors. J. thorac. cardiovasc. Surg., 35, 474.

Onuigbo, W. I. B. (1962). Multiple carcinomata of the lun (a case with three primary tumours). Brit.J. Dis. Chest, 56, 144.

Pirchan, A., and Sikl, H. (1932). Cancer of the lung in the miners of Jachymov. Report of cases observed in $1929 \boxminus$ 1930. Amer. J. Cancer, 16, 681.

Robinson, C. L. N., and Jackson, C. A. (1958). Multipla primary cancer of the lung. J. thorac. caridovasc. Surg 36, 166.

Shields, T. W., Drake, C. T., and Sherrick, J. C. (1964) Bilateral primary bronchogenic carcinoma. J. thorac cardiovasc. Surg., 48, 401.

Struve-Christensen, E. (1966). Bilateral primary broncho genic carcinoma. Report of one case. Acta chir. scand 131, 375.

Warren, S., and Gates, O. (1932). Multiple primary malignan tumors: a survey of the literature and a statistical study Amer. J. Cancer, 16, 1358.

Watson, A. J., Cameron, E. A., and Percy, J. S. (1964)ํㅜㄹ Multiple primary bronchial carcinoma. Report of two cases and a review. Brit. J. Dis. Chest. 58, 181.

Willis, R. A. (1967). Pathology of Tumours, 4th ed. Butter worths, London. 